\title{
UNSUR SUBSOSIALITAS KRIMINALISASI PERBUATAN \\ PADA PASAL 55 DAN 56 UNDANG-UNDANG TENTANG AKUNTAN PUBLIK
}

\author{
Nurini Aprilianda \\ Faizin Sulistio \\ Setiawan Noerdajasakti
}

\author{
Fakultas Hukum Universitas Brawijaya \\ Jl. Mayjen Haryono 169, Malang \\ aprilianda@yahoo.co.id, faizin@ub.ac.id; sakti@ub.ac.id
}

\begin{abstract}
This research explores the basic idea behind the use of aim of the is criminal provisions in Article 55 and 56 of Act Number 5 of 2011 of Public Accountants. The search to locate and to find the justification of criminal law in regulate public accounting actions that are considered dangerous and harmful to society. This study tried to criminal law as a means of crime prevention in Act Number 5 of 2011. The results can be concluded is the basic idea of the use of criminal law in Article 55 and 56 of Act Number 5 of 2011 is based on some legal reasons, namely: (1) Philosophically, it is as a safeguard against the profession as well as law protection, (2) To provide legal certainty the public accountants and law enforcement, (3) To create transparency and professionalism in making the financial statement audit, (4) Provide a deterrent effect, (5) Moral panic. The construction of the idea based on the concept of "subsocialiteit" and fears of harmful acts against the interests of the public accountant is realized by providing a model of criminalization that is expected to provide a balance in penal policy formulation, using a modeling and the legal principle approach (criminal).
\end{abstract}

Key words: criminalization, subsociality

\begin{abstract}
Abstrak
Penelitian ini dilakukan untuk menelusuri ide dasar yang melatarbelakangi penggunaan ketentuan pidana dalam Pasal 55 dan 56 Undang-undang Nomor 5 Tahun 2011 tentang Akuntan Publik. Penelusuran ini dilakukan untuk mencari dan menemukan dasar pembenaran yang digunakan untuk menggunakan sarana hukum pidana dalam pengaturan perbuatan akuntan publik yang dianggap berbahaya dan merugikan masyarakat. Penelitian ini mencoba mengkonstruksi penggunaan "teori subsosialitas" yang sangat berperan dalam ide pengunaan hukum pidana sebagai sarana penanggulangan kejahatan dalam Undang-undang Nomor 5 Tahun 2011. Hasil yang dapat disimpulkan adalah ide dasar penggunaan hukum pidana dalam Pasal 55 dan 56 Undang-undang Nomor 5 Tahun 2011 didasarkan pada beberapa rasio legis, yaitu: (1)Secara filosofis merupakan upaya perlindungan terhadap masyarakat sekaligus perlindungan profesi; (2)Memberikan kepastian hukum kepada akuntan publik dan penegak hukum; (3) Transparansi dan profesionalitas dalam pembuatan audit laporan keuangan; (4)Memberikan efek jera; (5)Kepanikan moral. Kontruksi terhadap ide yang disandarkan kepada konsep subsosialitas dan kekhawatiran akan berbahaya perbuatan akuntan publik terhadap kepentingan masyarakat diwujudkan dengan memberikan model kriminalisasi yang diharapkan memberikan keseimbangan dalam formulasi kebijakan penal, yaitu dengan menggunakan model pendekatan keseimbangan dan asas hukum (pidana).
\end{abstract}

Kata kunci: kriminalisasi, subsosialitas 


\section{Latar Belakang}

Masalah pokok dalam kebijakan kriminal dengan menggunakan sarana penal (hukum pidana) adalah mengenai penentuan perbuatan apa yang seharusnya dijadikan tindak pidana dan sanksi apa yang sesuai dengan karakter dari perbuatan tersebut. Oleh karena itu kebijakan pidana (penal policy), sebagaimana kebijakan publik umum yang lain, pada dasarnya harus merupakan kebijakan yang rasional, khususnya terkait dengan kebijakan legislatif dalam menetapkan dan merumuskan sesuatu di dalam peraturan perundang-undangan yang sering disebut juga dengan istilah kebijakan formulatif ${ }^{1}$. Hal ini dikarenakan kebijakan formulasi merupakan tahapan paling strategis dari keseluruhan proses operasionalisasi atau fungsionalisasi dan konkretisasi hukum pidana dalam rangka penanggulangan kejahatan di Indonesia

Politik Hukum Pidana Indonesia berjalan dalam arah yang tidak terencana secara baik, ini terlihat dengan berlarut-larutnya pengesahan RUU KUHP. Dampaknya kemudian satu persatu genus tindak pidana dalam KUHP dikeluarkan untuk disesuaikan dengan keadaan kontekstual dan pola kejahatan yang muncul. Akibat lebih lanjut beberapa peraturan hukum pidana menjadi tumpang tindih (overlapping) dan kriminalisasi yang berlebihan (over criminalization).

Keadaan over kriminalisasi ini diperparah dengan sangat gemarnya pembentuk undang- undang untuk mengkriminalkan perbuatan tertentu dalam peraturan perundang-undangan. Bahkan yang sedang menjadi trend dalam pembentukan peraturan perundang-undangan adalah penggunaan hukum pidana sebagai sarana pertama dan utama (primum remedium) dalam menyelesaikan permasalahan yang muncul dalam masyarakat, terutama dalam pengaturan profesi maupun dalam undangundang yang bersifat mengatur atau undangundang administratif.

Sebagai contoh kriminalisasi dalam Pasal 55 dan 56 Undang-undang Nomor 5 Tahun 2011 tentang Akuntan Publik (selanjutnya disebut UU Akuntan Publik) yang formulasinya cenderung menyentuh ranah privat etik dari profesi Akuntan Publik. Selain itu Para Akuntan Publik juga berpandangan bahwa keadaan subsosial juga belum terpenuhi dan ada kecenderungan bahwa pasal tersebut juga dianggap tumpang tindih dengan Pasal 263, 265 maupun Pasal 416 KUHP. Pandangan ini kemudian membuat beberapa Akuntan Publik kemudian mengajukan permohonan pengujian undang-undang kepada Mahkamah Konstitusi yang diregistrasi dengan Pengujian Perkara Nomor 84/PUU-IX/2011.

Uraian mengenai kriminalisasi perbuatan dalam profesi Akuntan Publik dan Pengujian undang-undang ini melatarbelakangi ketertarikan penulis untuk membahas proses kebijakan kriminalisasi yang dilakukan oleh pembentuk undang-undang khususnya

1 Barda Nawawi Arief, Bunga Rampai Kebijakan Hukum Pidana, Citra Aditya Bakti, Bandung, 1996, hlm. 245. 
mengenai argumentasi yang berkembang selama jalannya persidangan Perkara Nomor 84/PUU-IX/2011 mengenai Pengujian Pasal 55 dan 56 UU Akuntan Publik terhadap UUD 1945.

\section{Pembahasan}

\section{A. DasarPertimbangan Kriminalisasi} Perbuatan pada Pasal 55 dan 56 UU Akuntan Publik

Keinginan untuk melihat lebih jauh mengenai ide dasar konstruksi kriminalisasi dan penalisasi terhadap profesi akuntan publik yang diformulasi dalam Pasal 55 dan 56 UU Nomor 5 Tahun 2011 (selanjutnya disebut UU Akuntan Publik) adalah ramainya penolakan UU Akuntan Publik ini mulai dari tahapan RUU sampai pengesahan menjadi undang-undang oleh para Akuntan Publik di Indonesia.

Setelah diundangkan menjadi UU Akuntan Publik, beberapa akuntan publik yang didukung oleh IAPI mengajukan permohonan judicial review ke Mahamah Konstitusi terhadap Pasal 55 dan 56 UU Akuntan Publik dengan Nomor Register Perkara 84/PUU-IX/2011. Para pemohon menganggap bahwa keberadaan pasal tersebut sudah melihat profesi akuntan publik sebagai profesi "jahat" yang tidak membedakan antara profesionalisme dalam profesi yang seharusnya didudukkan dalam ranah privat etik dengan perilaku individu yang jahat dan kebetulan berprofesi sebagai akuntan publik, seperti tertuang dalam formulasi Pasal 55 dan
56 UU Akuntan Publik. Pasal 55 huruf a dan b

UU Akuntan Publik, yang berbunyi:

"Akuntan Publik yang:

a. melakukan manipulasi, membantu melakukan manipulasi, dan/atau memalsukan data yang berkaitan dengan jasa yang diberikan sebagaimana dimaksud dalam Pasal 30 ayat (1) huruf $j$;

b. dengan sengaja melakukan manipulasi, memalsukan, dan/atau menghilangkan data atau catatan pada kertas kerja atau tidak membuat kertas kerja yang berkaitan dengan jasa yang diberikan sebagaimana dimaksud dalam Pasal 3 ayat (1) sehingga tidak dapat digunakan sebagaimana mestinya dalam rangka pemeriksaan oleh pihak yang berwenang dipidana dengan pidana penjara paling lama 5 (lima) tahun dan pidana denda paling banyak Rp300.000.000,00 (tiga ratus juta rupiah)".

Pasal 56 UU Akuntan Publik, berbunyi:

"Pihak Terasosiasi yang melakukan perbuatan sebagaimana dimaksud dalam Pasal 55 dipidana dengan pidana penjara paling lama 5 (lima) tahun dan pidana denda paling banyak Rp300.000.000,00 (tiga ratus juta rupiah)"

Dalam risalah sidang DPR dan kronologis RUU tentang Akuntan Publik yang dikeluarkan oleh sekretariat Komisi XI DPR RI dapat diketahui beberapa pandangan mengenai ide, argumentasi dan alasan yang mendasari kriminalisasi dan penalisasi antara lain: 
Perdebatan yang alot mengenai formulasi perbuatan yang dilarang atau dikriminalisasi yang tertuang dalam risalah sidang pembahasan DIM RUU Akuntan Publik, masa persidangan III tanggal 31 Januari 2011 menggambarkan satu sisi kekhawatiran bahwa formulasi tersebut akan mengkriminalkan profesi akuntan publik terlihat dari pendapat awal Fraksi Partai Golkar dan Fraksi Partai Keadilan Sejahtera terhadap DIM 580 bab XII ketentuan pidana yang mengusulkan untuk dihapus. Sedangkan sisi yang lain semua fraksi sepakat bahwa sangat diperlukan perlindungan yang memadai terhadap pengguna jasa akuntan publik dan masyarakat secara umum.

Perwakilan Fraksi Partai Golkar (FPG) menyampaikan pendapatnya ${ }^{2}$ :

“...misalnya Pasal 63 ayat (2) disitu disebutkan akuntan publik yang dengan sengaja tidak memenuhi dan tidak melaksanakan standar profesi akuntan publik dan seterusnya itu dapat dihukum paling lama 4 tahun pidana dan denda dengan paling banyak 200 juta. Nah, ini kedengarannya agak aneh karena dia hanya melanggar profesi, melanggar standar yang dibuat oleh organisasi profesi. Oleh sebab itu, di manamanapun kalau organisasi itu atau jasa profesi diberikan itu kalau dia melanggar profesi, melanggar standar yang dibuat oleh profesi maka yang berhak menghukumnya itu adalah organisasi profesi itu, jadi tidak pidana itu salah satunya. FPG berpendapat... orang yang menyembunyikan informasi, menyembuyikan dokumen, memanipulasi keterangan, memalsukan dokumen itu ada pengaturannya dalam hukum pidana dan UU tentang Tipikor. Kenapa saya minta dihapuskan...profesi akuntan publik itu kurang diminati di indonesia sehingga jumlahnya masih sangat kecil, hanya sekitar 900 kantor Akuntan Publik yang ada padahal akuntannya puluhan ribu ya mungkin ratusan ribu. Ini kalau ditambah-tambah lagi dengan ditakut-takuti dengan pasal tentang pidana itu makin tidak mau orang masuk ke ruang akuntan publik ini...”.

Pada awal pembahasan ini terlihat kekurangsetujuan FPG dengan formulasi ketentuan pidana yang ditujukan kepada profesi karena ada potensi intervensi negara yang lebih jauh dalam kehidupan profesi. Menurut FPG kesalahan dalam profesi seharusnya diselesaikan melalui mekanisme internal profesi. Apalagi ditambah realita jumlah akuntan publik di Indonesia yang sangat sedikit dibandingkan dengan jumlah 
penduduk Indonesia, dikhawatirkan dengan pelekatan sanksi dan ketentuan pidana maka akan berdampak semakin menurunnya jumlah akuntan publik di Indonesia.

Pendapat senada disampaikan oleh Fraksi Partai Keadilan Sejahtera (FPKS) yang diwakili oleh Kemal Aziz Stamboel.

Sebagai perbandingan, di Singapura, penegakan terhadap pelanggaran aturan profesi akuntan publik dilakukan oleh Komisi Penyelidik di bawah Public Accountant Board yang berwenang menegakkan disiplin bagi para anggotanya. Singapura juga tidak mengatur larangan bagi akuntan dalam UU Akuntan Publiknya, hanya saja ditentukan bahwa akuntan publik harus mengikuti code of professional conduct and ethics. Sementara di Korea Selatan, larangan bagi akuntan publik hanya bersifat administratif yaitu dilarang memiliki dua kantor atau lebih dan dilarang menerima imbalan jasa bersyarat. Larangan-larangan yang ada di Amerika Serikat terkait profesi akuntan publik juga masih dalam batas jaminan akuntan publik dapat mempertahankan independensinya.

Pihak pemerintah yang mengusulkan RUU Akuntan Publik kemudian memberi penjelasan sebagai berikut:

"Pemerintah berpandangan
bahwa diperlukan ketentuan yang
mengatur sanksi pidana terhadap
akuntan publik dan kantor akuntan
publik sebagaimana telah diatur
dalam KUHP, secara khusus di
RUU pertama karena di KUHP bersifat umum. Dan memang di KUHP ya pasti disebutkan bahwa tindak pidana dikenakan sanksi bahkan juga dengan sanksinya juga sekaligus. Tetapi tidak secara spesifik sebagaimana dirumuskan dalam RUU ini menyebutkan bentuk-bentuk tindak pidana tersebut, misalnya di sini Pasal 63 ayat (1) disebutkan akuntan publik yang melakukan atau membantu memanipulasi data yang berkaitan dengan jasa yang diberikan, jadi spesifik Pak. Begitu juga di huruf $b$ nya yang dengan sengaja melakukan tindakan yang melibatkan kertas kerja dan atau dokumen lain yang berkaitan dengan pemberian jasanya tidak dapat dipergunakan,...kalau misalnya kita tidak mengatur secara spesifik disini Pak berartikan para penegak hukum kita nanti apakah polisi apakah juga kejaksaan mereka akan berpedoman semata-mata kepasal-pasal KUHP yang bersifat umum itu. Nah...pasal-pasal yang spesifik yang mengatur mengenai bentuk-bentuk perbuatan pidana tersebut ini akan membantu Pak untuk kepastian hukum baik bagi penegak hukumnya sendiri, baik bagi akuntannya sendiri Pak, untuk menghindari tidak terjebak ataupun tergoda untuk melakukan hal-hal 
yang jelas-jelas akan merupakan

perbuatan pidana".

Pihak pemerintah sebagai pengusul juga menambahkan, walaupun Pasal 263 dan 266 KUHP juga mengatur mengenai pemalsuan dan memberikan keterangan palsu dalam akta, tidak secara spesifik dalam bidang auditing. Pemerintah berargumen bahwa formulasi yang spesifik bukan sebuah kriminalisasi profesi malah perlindungan pada akuntan publik.

Pendapat berbeda yang mengkhawatirkan bahwa formulasi ketentuan pidana pada RUU Akuntan Publik dapat menghambat kerjakerja profesi khususnya terkait dengan "kertas kerja", karena dapat membuka peluang terjadinya kriminalisasi banyak dikemukakan oleh anggota Fraksi Partai Golkar (FPG) Kamarudin Syam.

Kekhawatiran terhadap kondisi ini sangat beralasan mengingat dalam dalam praktik akuntan, suatu kertas kerja tidak memiliki keseragaman, bahkan untuk klien yang samapun auditor yang berbeda akan membuat dokumentasi yang berbeda. Secara umum, dokumentasi sangat dipengaruhi oleh:

a. Tingkat risiko audit yang diinginkan oleh auditor;

b. Materialitas.

c. Pendekatan audit yang akan dipakai (system-based audit approach, risk-based audit approach, Substantive Procedures Approach, Balance Sheet Approach).
Sedangkan berdasarkan Laporan Panitia Kerja RUU Akuntan Publik Komisi XI DPR RI pada hari Rabu tanggal 30 Maret 2011 dinyatakan tujuan penggunaan sanksi administrasi dan ketentuan pidana dalam RUU Akuntan Publik adalah:

"Dalam memelihara kepentingan umum pengguna jasa Akuntan Publik diperlukan pengaturan terkait punishment dan penegakan hukum bagi kegiatan Akuntan Publik, Kantor Akuntan Publik dan Cabang Kantor Akuntan Publik. Tujuan ini dimaksudkan agar seorang Akuntan Publik senantiasa mengedepankan profesionalisme kinerjanya..."

Menurut Sutherland kerja-kerja melakukan kriminalisasi merupakan bagian dari kerja kriminologi yang meliputi membuat undangundang, pelanggaran terhadap undang-undang dan reaksi terhadap pelanggaran undangundang. Proses kriminalisasi termasuk dalam bagian pembuatan undang-undang, yaitu undang-undang pidana. Dalam tradisi kontinental proses pembuatan undang-undang selalu menjadi bagian yang tidak terpisah dari proses politik dalam parlemen. Dunia politik ini menembus dunia hukum melalui kebijakan kriminalisasi dengan panduan dari prinsip/asas hukum, aturan dan standar pembuatan undang-undang. Oleh karena itu dalam kajian kriminalisasi, minimal terdapat 2 permasalahan yang mendapat perhatian, 
yaitu materi kriminalisasi dan peranan undang-undang pidana secara umum serta penggunaan prinsip atau asas-asas hukum dalam kriminalisasi untuk mendapat justifikasi terhadap pemidanaan. ${ }^{3}$

Namun, apabila pembentuk undangundang kurang cermat dalam melakukan kriminalisasi perbuatan akan dapat merugikan hak konstitusional dari addresaat norm atau subjek hukum dari norma tersebut. Hal itu yang kemudian menjadi argumentasi permohonan uji materi perkara no 84/PUU-IX/2011 yang menganggap konstruksi Pasal 55 dan 56 UU Akuntan Publik tidak selaras dengan asas hukum pidana dan bertentangan dengan konstitusi. Menurut pemohon dalam perkara uji materi Pasal 55 dan 56 UU Akuntan Publik, kriminalisasi seharusnya mempertimbangkan secara mendalam mengenai perbuatan apa yang sepatutnya dipidana; syarat apa yang seharusnya dipenuhi untuk mempersalahkan/ mempertanggung jawabkan seseorang yang melakukan perbuatan itu; dan sanksi (pidana) apa yang sepatutnya dikenakan kepada orang itu. Sedangkan kriminalisasi dalam Pasal 55 dan 56 UU Akuntan Publik memperlihatkan ketidakjelian dalam menimbang dan mengukur antara perbuatan dengan pertanggungjawaban pidana yang harus diemban. Hal ini terlihat dengan tidak dipertimbangkannya ${ }^{4}$ :

1. Peran masing-masing subyek hukum antara orang yang melakukan tindak pidana dengan orang yang hanya memberi bantuan. Pasal 55 huruf a UU a quo yang tidak membedakan ancaman hukuman bagi pelaku petindak (pleger) dengan yang melakukan pembantuan (medeplichtigheid) tidak harmonis dan berseberangan dengan ketentuan Pasal 55 dan 56 KUHP. Rumusan yang membantu disamakan dengan pelaku adalah bertentangan dengan ketentuan Pasal 56 KUHP yang seharusnya ancaman pidananya dikurangi sepertiga. Dengan demikian Penormaan Pasal 55 huruf a UU Akuntan Publik bertentangan dengan asas-asas hukum pidana yang selalu mempertimbangkan kesalahan faktual (factual wrongdoer) dari masing-masing petindak.

2. Keseimbangan perbuatan masingmasing petindak dengan akibat yang ditimbulkan. Dalam Pasal 55 huruf a UU a quo yang memosisikan orang yang melakukan dan membantu melakukan dengan ancaman pidana yang sama bertentangan dengan asas setiap orang hanya dipertanggungjawabkan terhadap apa yang telah dilakukan. Apalagi delik dalam Pasal 55 huruf a ini merupakan delik formil yang mengatur perbuatanperbuatan yang dilarang, bukan delik materiil yang melarang akibat dari perbuatan yang dilakukan.

3 Nina Persak, Criminalising Harmful Conduct: The Harm Principle its Limit and Continental Counterpart, Springer, Netherland, 2007, hlm. 9-10.

4 Aan Eko Widiarto, Faizin Sulistio, M. Achsin dkk, Draft Permohonan Judicial Review Nomor Perkara 84/ PUU-IX/2011, 2011, Tidak dipublikasikan. 
3. Tidak dipertimbangkan unsur kesalahan (mens rea) dari diri petindak sebagai unsur yang menjadi alas seorang akuntan publik dapat dipertanggungjawabkan dalam hukum pidana menyebabkan kerancuan konsep dalam hukum pidana di Indonesia yang membedakan antara perbuatan (actus reus) dengan orang yang dipertanggungjawabkan.

Dengan demikian Pasal 55 huruf a UU a quo menimbulkan ketidakpastian dalam hukum dan bertentangan dengan prinsip lex certa yang menjadi prinsip dasar dalam hukum pidana. Ini bermakna pelanggaran atau bertentangan dengan Pasal 28 huruf D ayat (1) “UUD NRI 1945” khususnya anak kalimat "kepastian hukum yang adil""

Argumentasi pemohon ini sangat bertolak belakang dengan argumentasi pemerintah mengenai kepastian hukum. Hal ini dapat kita lihat dari proses perdebatan dalam rapat panja UU Akuntan Publik yang dinyatakan perwakilan pemerintah bahwa kepastian hukum akan lebih didapat oleh akuntan publik maupun masyarakat pengguna jasa apabila ada pengaturan yang lebih spesifik mengenai ketentuan pidana, karena penegak hukum (polisi dan jaksa) dapat melihat jelas perbuatan yang dilarang dalam UU Akuntan Publik tersebut.
Jawaban terhadap kekhawatiran pemohon uji materi UU Akuntan Publik mengenai aspek kepastian hukum juga disampaikan dalam tanggapan pemerintah dalam persidangan tanggal 12 Pebruari 2012 sebagai berikut ${ }^{6}$ :

“...Undang-undang Akuntan Publik juga telah memberikan kepastian hukum dengan mengatur batasan, kedaluwarsa dalam tuntutan pidana dan gugatan terhadap akuntan publik yang telah lewat dari lima tahun, serta perlindungan terhadap profesi akuntan publik dengan memberikan sanksi pidana yang lebih tinggi terhadap setiap orang maupun koorporasi yang bukan akuntan publik, tetapi menjalankan profesi akuntan publik dan bertindak seolah-olah selaku akuntan publik."

Pendapat pemerintah tersebut tidak secara khusus menjawab permasalahan yang dimohonkan. Sedangkan tanggapan pihak DPR lebih mencoba mengekplorasi perdebatan yang terjadi dalam rapat panja RUU Akuntan Publik ${ }^{7}$

"Bahwa akuntan publik dituntut untuk senantiasa meningkatkan kompetensi dan profesionalisme agar dapat memenuhi kebutuhan

5 Ibid.

6 Risalah Sidang Perkara Nomor 84/PUU-IX/2011 pada tanggal 2 Februari 2012.

7 Ibid. 
pengguna jasa dan mengemban kepercayaan publik. Untuk melindungi kepentingan masyarakat dan sekaligus melindungi profesi akuntan publik diperlukan suatu undang-undang yang mengatur profesi akuntan publik dengan tujuan untuk:

a. Melindungi kepentingan publik.

b. Mendukung perekonomian yang sehat, efisien, dan transparan.

c. Memelihara integritas profesi akuntan publik.

d. Meningkatkan kompetensi dan kualitas profesi akuntan publik.

e. Melindungi kepentingan profesi akuntan publik sesuai dengan standar dan kode etik profesi.

Selain itu tujuan formulasi norma dalam ketentuan pidana menurut DPR RI dimaksudkan untuk melindungi profesionalitas akuntan publik dan menjamin kepastian hukum bagi akuntan publik dan lebih khusus kepastian hukum bagi penegak hukum.

Terkait dengan keberadaan pasal-pasal dalam KUHP yang mengatur juga masalah pemalsuan, khususnya Pasal 263 ayat (1) dan 266 KUHP DPR tetap berpendapat masih perlu pengaturan spesifik untuk lebih melindungi akuntan publik dengan kepastian hukum. ${ }^{8}$

Sedangkan terkait dengan penggunaan istilah manipulasi yang menurut pemohon uji materi UU Akuntan Publik bermakna multitafsir dan menimbulkan ketidakpastian hukum, DPR RI berpendapat:

"Berdasarkan hasil pembahasan Panja RUU Akuntan Publik menurut ahli bahasa bahwa memalsukan bagian dari manipulasi. Jadi manipulasi itu lebih luas dari memalsukan. Memanipulasi itu bisa mengubah data, menggelapkan data, dan menyembunyikan data. Jadi tidak hanya memalsukan, kalau memalsukan yang dapat diartikan hanya mengganti yang betul dengan yang salah. Sementara kalau yang memanipulasi itu lebih luas dari pengertian memalsukan".

Jawaban DPR RI yang membenarkan pengertian manipulasi dapat digunakan karena punya pengertian yang meluas lebih abstrak sehingga dapat menjangkau beberapa perbuatan yang dianggap tercela. Sayangnya argumentasi kepastian hukum juga menjadi lebih tidak dapat diterapkan, karena penegak hukum dapat membuat interpretasi sendirisendiri mengenai makna manipulasi. Apalagi konsep manipulasi juga biasa digunakan atau menjadi terminologi yang digunakan secara positif dalam kode etik profesi.

Berdasarkan risalah pembahasan, pendapat akhir mini fraksi-fraksi dalam rapat panitia kerja (panja) komisi XI tentang RUU Akuntan Publik dan risalah sidang uji 
materi UU Akuntan Publik dengan nomor perkara 84/PUU-IX/2011 dapat diketahui beberapa argumentasi dan rasio legis yang hendak dibangun dalam melakukan formulasi norma ketentuan pidana UU Akuntan Publik khususnya yang kemudian dalam UU Nomor 5 Tahun 2011 menjadi Pasal 55 dan 56, yaitu:

1. Konstruksi dalam formulasi norma didasarkan pada argumentasi perlunya perlindungan hukum kepada masyarakat, khususnya masyarakat pengguna jasa Akuntan publik. Aspek perlindungan kepada publik ini menjadi mayoritas argumentasi fraksi dalam perdebatan yang berlangsung di dalam panja, pendapat akhir dari tiap-tiap fraksi maupun risalah sidang MK.

2. Konstruksi yang kedua didasarkan pada aspek kepastian hukum. Aspek kepastian hukum ini dikaitkan dengan formulasi yang lebih jelas dan spesifik terhadap perbuatan-perbuatan yang dilarang dan diberikan sanksi pidana sehingga dianggap lebih spesialis (lex spesialis) dibanding dengan formulasi dalam KUHP yang pengaturannya lebih umum. Pendapat yang agak nyeleneh disampaikan oleh pemerintah sebagai pengusul, yaitu formulasi yang spesifik terhadap perbuatan yang dilarang akan menghindari kriminalisasi terhadap profesi akuntan publik karena sudah mengetahui ketentuan yang dilarang. Argumentasi ini menunjukkan adanya ketidak samaan pemaknaan terhadap kriminalisasi itu sendari yang sebenarnya bermakna formulasi norma ketentuan pidana.

3. Konstruksi ketiga disandarkan pada terwujudnya aspek transparansi pelaporan keuangan oleh akuntan publik. Aspek ini lebih disandarkan pada pemberitaan terhadap kasus-kasus manipulasi keuangan oleh beberapa perusahaan besar didunia seperti Enron, world com yang diduga melibatkan akuntan publik dan kantor akuntan publik.

4. Konstruksi keempat disandarkan pada profesionalitas akuntan publik akan lebih meningkat dengan mengalihkan beberapa aturan kode etik seperti "kertas kerja" menjadi ranah publik sehingga dapat dibebani sanksi pidana. Bahkan menyatakan fraksi PAN sanksi pidana ditujukan kepada akuntan publik atau kantor akuntan publik yang melanggar Standar Profesional Akuntan Publik (SPAP), padahal seharusnya pelanggaran SPAP yang merupakan kode etik bagi akuntan Publik sebagai bagian ranah privat etik dapat digunakan penyelesaian dengan mekanisme internal organisasi dari profesi akuntan publik (IAPI).

5. Konstruksi kelima disandarkan pada efek jera. Pemberian sanksi pidana ini diharapkan oleh pembentuk undangundang dapat memberikan efek jera kepada akuntan publik yang nakal dan tidak melaksanakan tugasnya secara baik dan benar. 
6. Konstruksi keenam disandarkan pada kepanikan moral (moral panic) terkait dugaan keadaan global yang melibatkan akuntan publik nakal dalam beberapa kasus besar seperti Enron yang melibatkan KAP Artur Andersen, Satyam dan World com.

Ide dasar pengaturan profesi akuntan yang seharusnya merupakan gagasan penguatan profesi yang bersifat mendasar, yang dijadikan patokan atau orientasi sudut pandang menjadi tereduksi dengan adanya kriminalisasi dalam Pasal 55 dan 56 yang menimbulkan rasa takut dalam profesi akuntan. Padahal seharusnya dalam sebuah peraturan seharusnya merupakan konstruksi pikir (ide) yang mengarahkan hukum kepada cita-cita yang diinginkan profesi yang bersangkutan in casu profesi akuntan publik.

\section{B. Unsur Subsosialitas Sebagaimana} Diajarkan oleh Vrij dalam Kriminalisasi Perbuatan pada Pasal 55 dan 56 UU Akuntan Publik

Teori Subsosialitas pertama kali diperkenalkan oleh Vrij untuk menentukan dasar penjatuhan pidana terhadap seseorang, yang tidak hanya perbuatan tersebut harus melawan hukum (wedderechtelijkheid) dan dilakukan dengan kesalahan (schuld), masih juga harus memperhatikan keadaan yang subsosial. Keadaan subsosialitas ini adalah suatu keadaan sosial psikologis yang membawa akibat masyarakat gelisah, terganggu, kacau dan sebagainya. ${ }^{9}$

$$
\text { Ajaran Vrij mengenai keadaan }
$$
subsosial ini kemudian diaplikasikan dalam memandang anasir atau elemen yang ada dalam Strafbaarheid, meliputi: ${ }^{10}$

1. Elemen wederrechtelijkheid (unsur melawan hukum);

2. Schuld (unsur kesalahan); dan

3. Subsociale (unsur bahaya/gangguan/ merugikan)

Selain itu dalam penerapan hukum dan hukum acara, teori ini berkembang sejalan dengan asas Opportuniteit yang berupa pertimbangan kemanfaatan dalam hukum. Dalam konsep ini muncul pertimbangan bahwa suatu perkara dapat dikesampingkan dengan dasar pemikiran dapat memberikan ketentraman kepada masyarakat dengan cara bijaksana. Oleh karena itu apabila keadaan subsosial tidak terjadi maka delik pidana seharusnya tidak perlu dijatuhkan. Dalam artian suatu delik atau perbuatan yang akan dikriminalisasi seharusnya dapat diukur apakah mempunyai keadaan subsosial yang mendesak untuk dikriminalkan atau tidak.

Pengaturan mengenai profesi dalam bentuk peraturan perundang-undangan memang merupakan hal yang perlu dilakukan untuk memberikan perlindungan kepada profesi yang bersangkutan maupun kepada masyarakat pengguna jasa profesi tersebut. Namun seharusnya perlu pengkajian yang 
lebih mendalam dari sisi teoritik maupun kontektualitas mengenai mendesaknya suatu ketentuan pidana dibebankan dalam memberikan perlindungan tersebut. Maknanya dalam melakukan kriminalisasi terhadap suatu perbuatan yang dilarang diperlukan kecermatan dan kehati-hatian, sehingga tujuan yang mulia menjadi blunder dalam implementasi norma.

Seperti dalam pengaturan mengenai ketentuan pidana yang ditujukan kepada profesi, harus dibedakan mengenai apakah berbahanya suatu perbuatan yang akan dikriminalisasi muncul dari atribut individual dalam artian sifat batin yang jahat berhubungan dengan atribut individual personal ataukah sifat batin yang jahat berhubungan dengan sisi profesi dan profesionalisme yang berbasis pada profesi. Apabila tingkat bahaya dan kerugian yang ditimbulkan oleh sikap bathin jahat dari para profesionalisme ini memang demikian dasyat tetapi hal itu berhubungan dengan atribut yang bersifat individual, bukan dari profesi maka tidak perlu sebuah restriksi justisial dalam bidang hukum pidana yang akan malah lebih mengebiri profesionalisme sebuah profesi. ${ }^{11}$

Menjadi suatu masalah besar dan mematikan karakter profesi jika ada upaya mengintervensi standar profesi dan profesionalisme sebagai suatu bentuk perilaku jahat, yang terjadi adanya kriminalisasi profesi dan profesionalisme yang justru bukan antisipatif terhadap sikap jahat pada perilaku individual secara pribadi yang kebetulan menyandang profesi tertentu. ${ }^{12}$

Kondisi ini terjadi pada kebijakan formulatif yang dituangkan dalam UU No. 5 Tahun 2011 tentang Akuntan Publik, khususnya pada Pasal 55 dan Pasal 56 yang sudah mengkualifisir bahwa profesi Profesi Akuntan Publik merupakan profesi yang jahat. Padahal profesi Akuntan Publik diharapkan sebagai profesi yang memberikan jasa yang digunakan dalam pengambilan keputusan ekonomi dan berpengaruh secara luas dalam era globalisasi yang memiliki peran penting dalam mendukung perekonomian nasional yang sehat dan efisien serta meningkatkan transparansi dan mutu informasi dalam bidang keuangan.

Dengan demikian kebijakan formulatif dalam Pasal 55 dan 56 UU No. 5 Tahun 2011 tentang Akuntan Publik telah kontradiktif dengan legal spirit dari pengundangan ketentuan tersebut dan dapat dikatakan bahwa adanya ketentuan pasal dimaksud telah memposisikan profesi Akuntan Publik sebagai profesi yang cenderung bersifat jahat, dalam arti sudah dibedakan dari subyek-subyek hukum yang lain, atau tidak selaras dengan asas persamaan dihadapan hukum (equality before the law).

11 Agus Sudaryanto, Kriminalisasi Profesi dan Profesionalisme Akuntan Publik dalam Undang-undang No. 5 Tahun 2011 sebagai Wujud Pelanggaran Asas Equality Before The Law (Suatu Perenungan Sebagai Bahan Pertimbangan Kaji Ulang Kebijakan), Makalah dalam diskusi untuk permohonan Uji materi UU Akuntan Publik, 2011, Tidak dipublikasikan.

12 Ibid. 
Dalam teori ilmu hukum memang tidak ada yang secara ekplisit menuangkan konsep dan pedoman dalam melakukan kriminalisasi. Di Indonesia biasanya hanya dikaitkan formulasi norma undang-undang secara umum yang paling tidak memenuhi 3 (tiga) aspek, yaitu aspek filosofis, aspek yuridis dan aspek sosiologis. Aspek Filosofis menyangkut epistimologis, ontologis dan aksiologis. Aspek yuridis terkait dengan sinkronisasi dan harmonisasi dengan berbagi peraturan perundang-undangan, baik vertikal maupun horisontal. Sedangkan aspek sosiologis lebih pada aspek kontekstualitas kemasyarakatan.

Ilmu pengetahuan hukum pidana juga mengenal dan mempertimbangkan aspek sosiologis yang lebih dikenal dengan teori subsosialitas. Aspek subsosialitas ini adalah suatu keadaan sosial psikologis yang membawa akibat masyarakat gelisah, terganggu, kacau dan sebagainya. Dalam pandangan penulis konsep ini dapat disamakan dengan harm principle. Konsep subsosialitas ini turut diperhitungkan dalam menggali dan menelaah apakah suatu perbuatan atau aktivitas sudah patut untuk dikonstruksi sebagai suatu perbuatan pidana atau tidak. Artinya dalam melakukan kriminalisasi selain memperhatikan keselarasan asas dalam hukum pidana (schuld/kesalahan, sifat melawan hukum/ketercelaan perbuatan) juga harus melihat adanya gangguan yang nyata pada orang lain/masyarakat. Keadaan subsosialitas dalam kriminalisasi juga mempertimbangkan faktor korban (viktim), biaya, keadaan pelaku, ketakutan masyarakat dan luasnya akibat dari perbuatan yang dikriminalisasi.

Dalam konsep kriminalisasi ini, penulis mencoba menggunakan beberapa pendekatan sebagai dasar analisis bagi kriminalisasi dalam undang-undang akuntan publik. Pendekatan yang digunakan ialah pendekatan asas/prinsip hukum pidana yang dikongsikan dengan pendekatan keseimbangan yang dapat digunakan dalam tradisi kontinental, yaitu prinsip kemudaratan (harm principle).

Pendekatan keseimbangan ini muncul karena perkembangan hukum terkini yang dibentuk dalam negara modern membentuk sebuah karakter yang khas dari hukum yaitu rasional-artifisial. Karakter ini muncul karena undang-undang yang merupakan produk khas hukum tidak lagi diambil dari kaidah-kaidah tradisional yang tumbuh dalam masyarakat, melainkan diciptakan secara sengaja dan khusus. Lon L Fuller mendeskripsikan sebagai a system for governing human conduct by formally enacted rules. Struktur hukum moden bahkan menyiapkan parlemen atau badan legislatif sebagai kilang yang memproduksi undang-undang sesuai dengan apa yang oleh badan legislatif sesuai dengan perkembangan semasa dari masyarakat yang akan melaksanakan hukum tersebut.

Proses produksi hukum ini tidak lepas dari kepentingan berbagai pihak, baik pemerintah, masyarakat, pengusaha maupun komunitas internasional. Oleh itu dalam setiap proses kriminalisasi sesuatu perbuatan yang mengganggu masyarakat, perlu sebuah 
kajian yang holistik dan komprehensif dengan memperhatikan masyarakatnya. Hal ini diperkuat dengan konsep Mirror thesis yang dikemukakan oleh Tamanaha yaitu hukum haruslah merupakan pencerminan masyarakat atau komuniti dimana hukum tersebut diaplikasikan. Law is a mirror of society, which fucntions to maintain social order. ${ }^{13}$ Tesis Tamanaha ini memberikan warna baru dalam jurisprudens bahwa hukum memberi tempat dan peluang kepada sistem hukum bangsa yang bersangkutan. Bahkan Lawrence Friedman mengatakan bahwa sistem hukum tidak mengambang dalam ruang hampa budaya, bebas dari ruang, waktu dan konteks sosial, tetapi sistem hukum menggambarkan dan merefleksikan hal-hal yang terjadi pada masyarakatnya. Vago menambahkan, hukum merefleksikan keadaan intelektual, sosial, ekonomi dan politik semasa. ${ }^{14}$ Hal ini berarti bahwa dalam pengaplikasian hukum pidana dalam masyarakat haruslah mengandung prinsip-prinsip moral yang bersumber dari hukum adat atau kebiasaan yang baik dari masyarakat tempatan maupun yang bersumber dari ajaran agama yang dianut. Hal ini penting karena kepatuhan masyarakat terhadap hukum bukan saja karena takut dengan hukuman penjara yang diancamkan, melainkan pula karena dengan melakukan suatu perbuatan yang sejalan dengan prinsip yang diyakini (agama) maka secara tidak langgsung masyarakat menganggap sedang mengerjakan ibadah dalam agama yang akan mendapat ganjaran atau pahala.

Secara khusus Werner Menski juga melakukan kritik pakar hukum barat yang menyamakan sistem hukum sesuatu bangsa sebagai berikut, as western academics we seem, by our own histories and training, to be too wedded to ways perceiving and studying law that do not take sufficient account of the culture-spesicific embeddedness of legal phenomena in the world. Hal ini pula untuk mencegah terjadinya legal gap Legal gap atau lakuna dalam hukum dapat terjadi karena perbedaan karakter budaya yang dianut oleh suatu bangsa akan mempengaruhi perilaku hukum yang ada pada suatu masyarakat. Di sini gaps terjadi oleh sebab terjadinya perbedaan antar-tempat, yang bermakna juga sebagai perbedaan antar-konteks sosial-kultural, dan tidak lagi (hanya) karena peralihan konteks antar-waktu saja. ${ }^{15}$

Barda Nawawi secara khusus menyatakan bahwa pembaharuan hukum pidana haruslah bermaksud sebagai suatu upaya reformasi dan orientasi kembali hukum pidana yang sesuai dengan nilai-nilai sentral sosial politik, sosial filsafat dan sosial kultural masyarakat

13 Tamanaha, B.Z., A General Jurisprudenci of Law and Society, Oxford University Press, London, 2001, hlm. 1.

14 Ibid., hlm. 2

15 Soetandyo Wignjosubroto, Hukum: Konsep dan Metode, Makalah disampaikan The $2^{\text {nd }}$ Course On Strengthening Socio Legal Studies, Jakarta, 20-27 Mei 2008. 
Indonesia sebagai asas dari dasar sosial, dasar kriminalisasi dan dasar penguatkuasaan hukum di Indonesia. ${ }^{16}$

Oleh itu dalam kriminalisasi ini model yang coba digunakan oleh penulis adalah pendekatan keseimbangan dan pendekatan Asas-Asas hukum (khususnya hukum pidana).

Pendekatan keseimbangan digunakan untuk menetapkan dan menganalisa keadaan subsosial yang terjadi di Indonesia. Sedangkan penggunaan asas hukum Pidana lebih mengkaji aspek filosofi penggunaan hukum pidana dan sinkronisasi asas dengan peraturan perundangundangan yang mengatur ketentuan pidana.

\section{Pendekatan asas-asas hukum}

\section{a. Segi filosofi kriminalisasi}

Secara filosofi, kriminalisasi terhadap sesuatu perbuatan perlu dilakukan karena pada asasnya manusia merupakan makhluk yang otonom dalam berfikir dan bertindak yang berbeda dengan makhluk bumi yang lain. Kebebasan kehendak ini merupakan hak asasi ${ }^{17}$ yang wujud pada diri setiap individu, tetapi hak asasi ini disekat pula dengan hak asasi yang dimiliki oleh individu yang lain. Oleh itu setiap orang haruslah bertanggungjawab terhadap semua tindakan atau perbuatan yang dapat mengganggu hak asasi dari orang lain. Menurut Habermas aspek tanggungjawab dapat dilihat sebagai tanggungjawab bertindak (responsibility to act), Pemikiran Habermas ini mempunyai arti bahwa setiap tindakan haruslah disertai dengan tanggungjawab. Hal ini perlu karena setiap tindakan mempunyai implikasi-implikasi baik semantik maupun pragmatik, dengan pihak-pihak lain yang menjadi subjek tindakan tersebut. Dalam bahasa berbeda dapat dinyatakan bahwa setiap tindakan haruslah di landasi dengan cara-cara yang dapat dijustifikasi secara normatif. ${ }^{18}$

Pandangan berbeda dikemukakan pendukung posmodernism yang menyatakan bahwa aspek tanggungjawab haruslah berdasar pada konsep tanggungjawab terhadap pihak lain (a responsibility to otherness), yaitu tanggungjawab memberi tempat dan menyediakan ruang untuk perbedaan (difference), ironi bahkan ambiguitas. Pemikiran ini mempunyai arti bahwa setiap individu haruslah menyediakan ruang-ruang bagi pihak lain untuk berbicara (to speak), agar dia dapat dipahami. Tanggungjawab terhadap orang lain ini, disatu pihak memberi hak untuk memahami dan dipihak lain memberi tempat atau ruang untuk berbicara. ${ }^{19}$

16 Barda Nawawi Arief, Pembaharuan Hukum Pidana: dalam Perspektif Perbandingan, Citra Aditya Bakti, Bandung, 2005, hlm. 4.

17 Hak asasi merupakan hak yang dimiliki oleh seseorang sebagai bagian dari masyarakat. Hak ini dibatasi oleh hak asasi orang lain dan kepentingan masyarakat. Ruang lingkup atau batasan hak asasi manusia ini diturunkan dari dialektika perlembagaan, yang di sandarkan pada sentimen marwah manusia.

18 Yasraf Amir Piliang, Dunia yang Dilipat: Tamasya Melampaui Batas-batas Kebudayaan, Jalasutra, Yogyakarta, 2004, hlm. 219.

19 Ibid. 
Dalam pendapat penulis, pandangan Habermas $^{20}$ yang mencoba melanjutkan tradisi modernism ataupun pendukung posmodernism mempunyai arti penting untuk memahami posisi tanggungjawab dari individu, yaitu bahwa sejalan dengan pemikiran Habermas, sebelum bertindak dan melakukan perbuatan, kita harus melihat dampak dari tindakan yang kita lakukan, yakni apakah tindakan yang kita lakukan mengganggu atau menyerang kepentingan individu orang maupun masyarakat? Apakah perbuatan kita dapat menimbulkan kerugian atau kerusakan bagi pihak lain? Dengan melakukan perkiraan terlebih dahulu tindakan kita, maka kitapun mempunyai alternatif tindakan atau perbuatan yang sejalan dengan norma-norma yang dianut oleh masyarakat.

Pendekatan kebijakan penal atau pendekatan dengan hukum pidana selalu terkait dengan penentuan mengenai (1) aktivitas-aktivitas apa saja yang seharusnya dijadikan aktivitas pidana, dan; (2) sanksi apa saja yang dapat digunakan atau dikenakan kepada si pelanggar. Untuk menetapkan sesuatu aktivitas sebagai suatu aktivitas pidana, perlu memperhatikan kriteria-kriteria, interalia:

1. Apakah aktivitas itu dicela oleh masyarakat karena merugikan atau mendatangkan korban
2. Apakah biaya menjadikan suatu aktivitas sebagai pidana seimbang dengan keadaan ketertiban dan tertib hukum yang diharapkan.

3. Apakah penguat kuasa hukum mampu menegakkan hukum terhadap aktivitas tersebut

4. Apakah aktivitas tersebut berbahaya bagi cita-cita bangsa sehingga berbahaya untuk masyarakat.

Kriteria umum mengenai penetapan suatu aktivitas sebagai pidana di atas sangat memperhitungkan mengenai prinsip harm dalam sesuatu perbuatan terhadap masyarakat. Hal ini menunjukkan bahwa kriteria utama dalam kriminalisasi ialah berkaitan dengan aspek nilai-nilai moral yang ada dalam masyarakat. Sesuatu aktivitas dicela karena aktivitas tersebut keluar dari kerangka nilai-nilai moral yang dianut oleh masyarakat. Selain itu aspek biaya pula menjadi bahan pertimbangan kriminalisasi karena penegakan terhadap sesuatu hukum, apalagi aktivitas dengan menggunakan teknologi modern perlu biaya yang besar dan kemampuan ilmu pengetahuan dari penegak hukum. Kriminalisasi terhadap sesuatu aktivitas haruslah upaya terakhir (ultimum remedium) karena kerusakan dan bahaya yang dapat berdampak pada orang banyak dalam masyarakat.

20 Habermas secara konsep berdiri pada tradisi modernitas Descartes dan Kant yang menganggap penting nalar dan rasio dalam memahami dunia. Tetapi Habermas menolak asas kesadaran dari pemikiran para pakar filsafat tersebut, dan beralih pada asas bahasa dan tindakan komunikatif. Dalam tradisi modernitas Habermas hanya mempertahankan konsep standar universal rasionalitas. Hal inilah yang membedakan Habermas dengan penyokong tradisi posmodern yang menolak rasionalitas dan universalitas, untuk mencari alternatif dari perbedaan, yaitu penghargaan akan fragmentasi, heterogenitas, lokalitas dan pluralitas, dengan mencipta ruang-ruang bagi perbedaan. 
Selain itu Menurut Husak Penggunaan hukum pidana diperlukan untuk melakukan kriminalisasi karena beberapa alasan, yaitu: ${ }^{21}$ (1) model untuk mencegah kemudaratan (harm); (2) melarang tingkah laku yang salah; (3) memaksakan hukuman yang layak; (4) pemerintah tertarik mengubah hukum sehingga hukum menjadi kokoh; (5) Hukum tersebut secara langsung memajukan tujuan pemerintah; (6) Hukum tersebut haruslah tidak lebih luas dari keperluan yang menjadi tujuan yang ingin dicapai pemerintah.

Dalam mengontrol aktivitas pidana, hukum pidana selalu mengkaitkan dengan teori hukuman (punishment theory) yang berkembang dalam doktrin hukum pidana dan jurispruden. Teori hukuman ini berhubungan dengan pertanggungjawaban yang dilakukan seseorang karena melakukan suatu aktivitas pidana. Menurut Garlan tujuan hukuman dapat dimaknai dari tiga aspek, yaitu pertama dari segi filsafat hukuman, kedua dari segi hukum dan keteraturan sosial, terakhir dari segi sosiologi hukuman. Dalam kerangka hukum pidana tujuan yang ingin dicapai lebih khas, yaitu mengurangi dan mencegah pidana. Hukuman disini memerhatikan tidak saja dari sudut pandang keadilan, tetapi lebih kepada kepraktisan, yaitu hukuman yang dapat mencegah pelaku kejahatan? Dapatkah pelaku tindak pidana dapat dipulihkan? Segi yang ketiga diperhitungkan dari hukuman dan masyarakat serta relasi yang terjadi. ${ }^{22}$

Sedangkan menurut Hall hukuman yang dilakukan terhadap pelaku tindak pidana harus memenuhi dua perkara, yaitu layak dan efektif (suitable and effective). Aspek layak ini ditujukan kepada aktivitas yang mengganggu dan berbahaya bagi masyarakat sehingga patut untuk diberikan sanksi terhadap siapa saja yang melakukan aktivitas ini. Sedangkan aspek efektif ini ditujukan kepada aktor yang melakukan aktivitas sehingga tidak mencoba melakukan ataupun mengulang aktivitas yang melanggar hukum. Selain itu efektifitas pula ditujukan kepada siapa saja untuk tidak mencoba melakukan suatu perbuatan pidana.

Hukuman dalam pandangan Hart mempunyai lima elemen penting yaitu: "it must involve pain or other unpleasant consequences, it must be as a result of an offence againts a legal rule, there must be an actual or supposed offender, it must be intentionally administered, and it must be imposed by legal authority againts which the offence was commited"23. Dalam konsep Hart ini, akibat yang menyakitkan dan tidak menyenangkan ini mempunyai banyak variasi, yaitu hukuman mati, penjara, dirusakkan atau dihapuskan barang atau hak yang dimiliki,

21 Kimberley Brownlee, Justifying Punishment: A response to Douglas Husak, Criminal Law and Philosophy, Volume 2 Issue 2 June 2008, 2008, hlm. 126-127.

22 Uri j. Schild, Criminal Sentencing and Intelligent Decision Support, Journal Artificial Intelligent and Law, Volume 6: 151-202, 1998, Kluwer Academic Publishers, Netherland.

23 H.L.A Hart, Punishment and Responsibility: Essays in the Philosopy of Law, Oxford University Press, London, 1968, hlm. 4-5. 
hukuman denda, deportasi ataupun dibuang sebagai warganegara. ${ }^{24}$ Semua perkara yang menyakitkan dan penuh derita ini merupakan ganjaran negara terhadap semua tindakan dan perilaku yang melanggar kedaulatan hukum.

\section{b. Segi asas hukum (pidana)}

Asas hukum dalam proses kriminalisasi sebenarnya mengkaji mengenai hukum pidana substantif yang memuat tiga hal penting, yaitu subjek hukum pidana, perbuatan yang dilarang dalam hukum beserta hukuman yang diancamkan terhadap pelanggaran yang terjadi. Karakter hukum pidana biasanya melakukan pembatasan terhadap hak manusia untuk kepentingan ketertiban masyarakat. Tata tertib dalam masyarakat ini akan kekal apabila tidak ada tindakan atau perilaku dari anggota masyarakat yang melanggar nilai-nilai moral yang dianut oleh masyarakat setempat. Apalagi tindakan itu wujud sebagai tindakan imoral yang menyerang dan mengganggu kepentingan hukum, baik kepentingan individu ataupun masyarakat. Pada proses ini terjadi hubungan antara hukum, secara khusus hukum pidana dengan moral. Banyak para pakar dari berbagai mazhab mencoba melakukan kajian mengenai hubungan antara hukum dan moral. Hakim Stephen pula menyatakan: ${ }^{25}$

“...Hubungan yang paling dekat antara hukum pidana dengan sentimen moral dalam segala hal adalah sehat dan banyak mendatangkan banyak kebaikan kepada masyarakat. Pada pendapat saya, pelaku pidana sepatutnya perlu dibenci. Hukuman yang dikenakan kepada mereka setidak-tidaknya dapat menggambarkan kebencian tersebut, dan logis sebuah peraturan dilahirkan sebagai cara memuaskan sentimen biasa dan sehat dilogiskan dan dilakukan".

Seorang sarjana hukum Green mencoba mengkaji hubungan antara hukum dan moralitas ini sebagai prinsip kriminalisasi. Prinsip itu meliputi culpability, harmfulness dan wrongfulness.

1) Prinsip Culpability;

Makna dari culpability oleh Green ialah "the moral value attributed to a defendant's state mind during the commision of a crime" 26 Ciri nilai moral pada mind pelaku dalam

24 Douglas Husak, Why Criminal Law: A Question of Content?, Journal Criminal Law and Philosophy Volume 2:99-122, 2008, hlm. 102.

25 Smith and Hogan, Undang-undang Jenayah Bagian I Prinsip Umum, Terjemahan oleh Jamilah Abdul Rauf dan Raja Rohana Raja Mamat, Dewan Bahasa dan Pustaka, Kuala Lumpur, 1996, hlm. 5.

26 Green, "Why It's a Crime to Tear the Tag off Mattress, in Caron Beaton-Wells, "Capturing the Criminality of Hard Core Cartel: The Australian Proposal", Melbourne University Law Review, Volume 313 November 2007, Melbourne, 2007, hlm. 681. 
melakukan perbuatan pidana ini merupakan bagian dari kesalahan ${ }^{27}$ (mens rea) yang dapat menjadi syarat dalam pertanggungjawaban dari pelaku. Oleh itu Green menyatakan bahwa "culpability reflect the degre to wich an individual offender is blameworthy or responsible or can be held accountable". ${ }^{28}$ Hal ini berarti bahwa suatu perbuatan pidana dapat dipertanggungjawabkan oleh pelaku karena perbuatan tersebut mengandung nilainilai moral yang dicela oleh masyarakat. Bahkan Jeferson menyatakan, criminal resonsibility is largely founded on moral culpability, ${ }^{29}$ yaitu pertanggungjawaban pidana secara umum berawal dari kesalahan moral. Jerome Hall pula menyatakan dalam essainya yang berjudul "Negligent Behaviour Should be Excluded From Penal Liability". Dalam essai ini beliau berargumen bahwa "No one should be punished unless he has clearly acted immorally". Argumen ini secara tegas menyatakan tidak dapat seseorang mendapat hukuman, kecuali dia telah nyatanyata melakukan perbuatan tidak bermoral. Untuk dapat dikatakan sebagai tindakan yang tidak bermoral syaratnya menurut Hall ialah tindakan tersebut haruslah dilakukan secara sukarela (voluntary) dan meliputi kecederaan terhadap seseorang (involves harm to someone). Untuk menentukan macam-macam tingkah laku/perbuatan/ tindakan yang dapat disebut tidak bermoral, terkadang negara dengan kewenangannya melakukan kriminalisasi terhadap sesuatu perbuatan. Inisiatif kriminalisasi oleh negara ini diharapkan akan membuat masyarakat ikut menolak perbuatan jahat dan menganggapnya sebagai perbuatan yang tidak bermoral. Anggapan masyarakat bahwa seseuatu perbuatan tidak bermoral pada suatu perbuatan yang dijadikan sebagai perbuatan pidana, akan memantapkan sistem hukum nasional terkait dengan nilai-nilai moral yang dianut oleh masyarakat setempat tersebut. Hal ini dinyatakan oleh Hart bahwa "the stability of legal systems depends in part upon such types of correspondence with morals". ${ }^{30}$

Dalam realitas di masyarakat, ada saja tingkah laku yang dipandang melanggar moral dan tidak baik, tetapi oleh hukum tidak dimasukkan sebagai perbuatan pidana karena tingkat ancaman dan kerusakan terhadap masyarakat dianggap tidak terlalu besar. Oleh itu kriminalisasi sesuatu perbuatan atau tingkah laku oleh hukum menjadi suatu perbuatan pidana diikuti pula oleh

27 Prinsip culpability (mens rea) dalam sistem hukum Eropa Kontinental dikenal pula dengan prinsip "Geen straf Zonder Schuld"," Keine Strafe Ohne Schuld" yang mempunyai sinonim dengan istilah No Punishment Without Guilt. Dalam KUHP di Indonesia prinsip ini tidak secara tegas/ekplisit terwujud dalam ayat-ayat dalam undang-undang. Prinsip ini lebih berkembang dalam doktrin hukum yang kemudian menjadi asas keputusan hakim. Dalam konsep kriminalisasi seterusnya prinsip ini perlu secara ekplisit dimasukkan dalam konsep KUHP untuk keseimbangan dengan prinsip legaliti (Nullum delictum nula poena sine previa lege poenale).

28 Green, Op.cit.

29 Michael efferson, Criminal Law, Pitmann, London, 1999, hlm. 5.

30 HLA. Hart, The Concept of Law, Clarendon Press, Oxford, 1961, hlm. 204. 
harapan bahwa perbuatan tersebut menjadi perbuatan tercela atau tidak bermoral dalam pandangan masyarakat. Hal ini sejalan dengan pemikiran Murphy yang menyatakan bahwa, law as a total phenomenon arises within, and its understood by evolutionary human consciousness. ${ }^{31}$ Hukum selalu lahir karena terjadi perkembangan dalam peradaban dan budaya manusia.

Dalam kontek Indonesia eksplorasi nilai-nilai moral ini harus bersumber pada Pancasila yang mengandungi idea dasar wujudnya keseimbangan nilai: moral religius (ketuhanan); kemanusiaan (humanistik); kebangsaan; demokrasi dan keadilan sosial. ${ }^{32}$ Eksplorasi nilai-nilai yang bersumber dari Pancasila ini tidak dengan mengalienasi nilainilai yang berasal dari nilai-nilai religius dan adat istiadat budaya lokal, melainkan suatu proses terpadu untuk mendukung nilai-nilai yang baik dalam masyarakat dengan hukum positif.

\section{2) Prinsip kemudaratan (harmfulness)}

Green membuat pemaknaan mengenai harmfulness untuk the degree to which a criminal act causes (or risk causing) harm. He adopt a definition of harm as some relatively lasting or significant setback to person's interest. ${ }^{33}$ Konsep interes/kepentingan disini meliputi kepentingan individu maupun kepentingan kumpulan. Dengan konsep mengenai kepentingan hukum yang dilanggar, maka dapat dikata bahwa untuk melakukan kriminalisasi sesuatu perbuatan perlu adanya kepentingan hukum yang diganggu atau dicederai. Kepentingan ini meliputi dua hal, yaitu kepentingan publik dan kepentingan individu/privat. Beberapa hal yang termasuk dalam kepentingan publik antara lain: ${ }^{34}$

1. Preventing physical injury. This acounts for the crimes of murder, manslaughter, arson and other crimes of violence;

2. Proscribing personal immorality deemed injurious to society's well-being. This accounts for crimes such as bigamy, incest, sado-masochism.

3. Preventing the moral corruption of the young through crimes such as gross indecency with children and unlawful sexual intercourse;

4. Maintaining the integrity of the state and the administration of justice, through crimes such as treason, perjury, perventing the cours of justice, tax evasion;

5. Maintaining public order and security through offence such as riot, affray, breach of peace, public drunkenness.

Sedangkan yang berhubungan dengan

31 Chairul Huda, Dari Tiada Pidana Tanpa Kesalahan menuju kepada Tiada Pertanggungjawaban Pidana Tanpa Kesalahan, Prenada Media, Jakarta, 2006, hlm. 67.

32 Yesmil Anwar dan Adang, Pembaruan Hukum Pidana: Reformasi Hukum, Gramedia Widiasarana Indonesia, Jakarta, 2008, hlm. 2.

33 Green, Op.cit.

34 Wilson, William, Criminal Law: Doctrine and Theory, Longman Limited, UK, 1998, hlm. 6. 
kepentingan individu, yaitu terbebas dari: ${ }^{35}$

1. Undesired physical interference through crimes such as rape, assault, indecent assault, false imprisonment, harrasment;

2. Offence through crimes such as indicent exposure, indecency in public solicitation;

3. Undesired interference with property through crimes such as theft, robbery, taking and driving away a road vehicle, deception.

\section{3) Elemen wrongfulness}

"violation of moral norm that occur when criminal act commited". ${ }^{36}$ Dapat dikatakan bahwa wrongfulness merupakan bentuk pelanggaran terhadap norma moral yang terdapat dalam masyarakat. Sehingga batas bahwa sesuatu perbuatan atau pembiaran (omision) merupakan perbuatan pidana ialah perbuatan tersebut oleh komunitas sosial dianggap sebagai pelanggaran terhadap normanorma moral yang sedang berlaku. Wrongful merupakan tindakan yang melanggar hukum karena hukum manifes dengan norma-norma moral positif yang diyakini sebagai rujukan dalam bertingkah laku.

Dari tiga elemen yang oleh Green menjadi argumen kriminalisasi dalam kajian hukum, yaitu culpability, harmfulness dan wrongfulness yang terkait antara hukum dan moralitas, yang mempunyai peran besar untuk menjadikan sesuatu perbuatan sebagai sebuah pidana yang perlu diatur dalam undangundang adalah aspek harm/kemudaratan yang menimbulkan impak dan akibat kepada korban. Argumentasi prinsip ini lahir dari teori otonomi yang dimiliki oleh manusia, yaitu pada dasarnya manusia merupakan makhluk yang diberi kemampuan untuk mengawal takdirnya. Manusia diciptakan sebagai manusia yang bebas dan mempunyai pilihan yang rasional sebagai individu. Pilihan dan tindakan rasional yang bebas dari manusia inilah yang secara natural dan hubungan sosial menjadikan manusia sebagai agen moral otonom yang dibatasi tanggungjawab terhadap tindakannya yang baik atau jelek. Dalam masyarakat yang liberal, premis manusia sebagai agen moral otonom yang mempunyai kebebasan dalam memilih dan bartindak, dalam hubungan antara individu dan negara dapat diguna pakai sebagai dasar untuk melakukan evaluasi terhadap sistem aturan yang bersifat memaksa dan hukuman terhadap pelanggaran yang dilakukan. Aturan yang bersifat memaksa dijadikan justifikasi terhadap fakta bahwa tindakan manusia untuk meningkatkan derajat sebagai makhluk yang otonom dibanding untuk melakukan pembatasan. Sebagai subjek yang rasional dan makhluk yang bebas mempunyai pilihan untuk mampu menyesuaikan atau tidak terhadap aturan standar, sebagai petunjuk dalam hidup dengan minimal risiko gangguan yang tidak menyenangkan. ${ }^{37}$

Terkait dengan kriminalisasi dalam UU Akuntan Publik khususnya Pasal 55 
dan 56, penulis sepakat dengan keterangan ahli pemohon Mudzakir yang menyatakan kriminalisasi harus sesuai dengan asas legalitas dalam perumusan delik, konsekuensinya harus memenuhi prinsip lex scripta, lex certa dan lex stricta. Yakni suatu perbuatan dilarang dan diancam dengan pidana dirumuskan secara jelas dan tegas, rinci mengenai unsurunsur perbuatan dilarang. Sehingga tidak ada perumusan yang ambigu mengenai perbuatan dilarang yang dikenakan sanksi pidana. Jadi melalui perumusan yang jelas, tegas tersebut akan diketahui secara pasti perbuatan mana yang dilarang oleh undang-undang dan perumusan yang tidak jelas dan tidak tegas, bermakna ganda, atau serba mencakup akan menimbulkan ketidakpastian hukum. ${ }^{38}$

\section{Pendekatan keseimbangan}

\section{a. Faktor sosiologis}

Argumentasi terakhir untuk mendukung kriminalisasi adalah argumentasi dari faktor sosiologis. Argumen ini mencoba mengaitkan mengenai kriminalisasi dengan aspekaspek yang berkaitan dengan kepentingan masyarakat dan permasalahan yang bersifat empirik. Proses kriminalisasi ini ditujukan untuk melindungi dan menjaga kepentingan dari masyarakat, sehingga kriminalisasi hanya perlu apabila sesuatu perbuatan berbahaya bagi masyarakat. Selain itu hukuman untuk suatu perbuatan yang dianggap sebagai perbuatan pidana, haruslah terbatas dengan nilai-nilai kepentingan masyarakat yang dilindungi. Kepentingan masyarakat tersebut, yaitu memelihara tata tertib masyarakat; melindungi masyarakat dari kejahatan, gangguan dan bahaya yang dilakukan oleh orang lain; memelihara pandangan mengenai keadilan sosial, maruah kemanusiaan dan keadilan individu.

Perlindungan kepentingan masyarakat ini memberikan rumusan bahwa argumentasi dari segi sosiologi menggunakan pendekatan yang berdasar pada nilai-nilai moral yang diyakini oleh masyarakat, sehingga tidak hanya bersifat pragmatis belaka. Selain itu, yang perlu diberi penekanan dalam melakukan kriminalisasi ialah faktor-faktor mengenai: ${ }^{39}$ (a) keseimbangan antara cara yang digunakan dengan hasil yang diperoleh; (b) analisis biaya terhadap hasil yang diperolehi terkait dengan tujuannya; (c) penilaian objektif yang dicari terkait prioritas pengaturan sumber tenaga manusia; (d) dampak sosial dari criminalization dan decriminalization dalam akibat sekunder.

Argumentasi sosiologi kriminalisasi pula meliputi hal yang bersifat praktikal, yang berupa kecederaan atau kemudaratan terhadap orang awam. Bahkan faktor kemudaratan itu tidak harus berkaitan dengan aspek moral, melainkan pula sesuatu yang dapat menghalang kepentingan orang, misalnya:

1. The impact of the conduct on the market

2. The scale of detriment, loss or damage to

38 Ibid.

39 Keterangan ahli Pemohon Mudzakir dalam Risalah Sidang Perkarta Nomor 84./PUU-IX/2011 tanggal 14 Februari 2012, hlm. 12. 
consumer or the public;

3. Wether one or more of the participants had previously been found to have engaged in conduct, or had admitted to doing $\mathrm{so}^{40}$

\section{b. Faktor pengaturan profesi}

Menjalani suatu profesi akuntan publik adalah perwujudan dari hak untuk bekerja, hak mengembangkan diri, serta hak untuk memperoleh manfaat dari ilmu pengetahuan. Untuk dapat menjalankan profesi tersebut tentu seseorang harus dipenuhi rasa aman dan perlindungan dari ancaman ketakutan untuk berbuat sesuatu atau tidak berbuat sesuatu sesuai tuntutan profesi. Apalagi di dalam menjalankan suatu profesi mutlak diperlukan adanya keahlian yang tidak dimiliki oleh setiap orang, yang berdasarkan keahlian itulah semua pertimbangan untuk melakukan sesuatu atau tidak melakukan sesuatu harus diletakkan. Untuk dapat menjadikan keahlian sebagai dasar pertimbangan utama dalam melakukan sesuatu atau tidak melakukan sesuatu, diperlukan adanya independensi dari kepentingan atau pengaruh apapun selain dari keahlian itu sendiri. Oleh karena itu suatu profesi hanya dapat dijalankan jika terdapat rasa aman dan perlindungan dari ancaman ketakutan untuk menjalankan profesi itu.

Dalam perkembangan peraturan perundang-undangan muncul beberapa produk hukum yang mengatur profesi-profesi tertentu. Pengaturan ini setidaknya memuat tiga aspek. Pertama, memastikan bahwa hanya orang yang memiliki keahlian-lah yang dapat menjalankan profesi tertentu. Kedua, memberikan perlindungan kepada profesi tertentu dari hal-hal yang dapat merugikan atau mengganggu profesi. Ketiga, memberikan perlindungan kepada masyarakat. ${ }^{41}$

Terdapat kecenderungan tarik ulur antara tujuan kedua dan ketiga, yaitu antara memberikan perlindungan kepada profesi terutama dalam hal menjaga independensi dengan tujuan memberikan perlindungan kepada masyarakat agar benar-benar mendapatkan layanan yang profesional. ${ }^{42}$

Dilihat dari aspek berprofesi, maka bekerja itu masuk hak sosial (social right). Dalam konsep HAM, sosial right itu dikategorikan sebagai positive legal right yang memberikan kewajiban pada negara untuk melakukan pemenuhan (fulfill). Oleh sebab itu, melakukan pengaturan yang sifatnya pidana/ kriminal akan berdampak pada terbatasnya hak menjalankan profesi. Untuk menganalisis apakah terdapat pelanggaran kode etik, atau standar etik tersebut, maka diperlukan standard perilaku yang dirumuskan oleh kelompok profesi dimaksud. Oleh sebab itu, perlu dihindarkan intervensi pemerintah/ penguasa yang dapat menjadi penghambat atau penghalang berfungsinya profesi secara efektif. ${ }^{43}$

Sedangkan seharusnya masuknya kewenangan pemerintah dalam kegiatan

40 Barda Nawawi Arief, Bunga... Op.cit., hlm. 29.

41 Green, Op.cit.

42 Keterangan Ahli Pemohon Mochammad Ali Safaat dalam sidang Perkara Nomor 84/PUU-IX/2011.

43 Ibid. 
profesi, adalah kewenangan melalui sistem perijinan; di luar sistem perijinan maka tidak ada kewenangan pemerintah yang dapat dijalankan. Ijin adalah instrumen yang digunakan oleh pemerintah untuk mengendalikan aktivitas warga agar tercapi sebuah tujuan tertentu. ${ }^{44}$

Penulis sepakat dengan pendapat Ahli Pemohon Yusril Ihza Mahendra yang menyatakan perumusan norma dalam Pasal 55 huruf $\mathrm{b}$ Undang-undang a quo jelaslah tidak menjamin adanya kepastian hukum, sehingga bertentangan dengan norma Pasal 28D ayat (1) Undang-undang Dasar negara Republik Indonesia Tahun 1945. Rumusan itu juga menimbulkan rasa khawatir dan ketakutan untuk melakukan pekerjaan yang merupakan profesi dari seorang akuntan publik karena pekerjaannya dapat dinilai, dapat digunakan sebagai mana mestinya atau tidak oleh instansi-instansi yang sama sekali tidak mempunyai kualifikasi dan otoritas untuk melakukan penilaian. Dibandingkan dengan profesi lain seperti profesi notaris, advokat, dan kedokteran, masalah yang terkait dengan ada tidaknya malpraktik dalam menjalankan profesi pertama-tama haruslah diperiksa oleh majelis kode etik atau dewan kehormatan profesi sebelum diserahkan kepada aparat penegak hukum. Ancaman pidana yang diberikan oleh Pasal 55 Undang-undang a quo yang langsung mempidanakan dugaan pelanggaran etika profesi mengandung sifat diskriminatif yang bertentangan dengan Pasal 28I ayat (2) Undang-undang Dasar negara Republik Indonesia Tahun $1945 .{ }^{45}$

\section{Simpulan}

Ide dasar dalam konstruksi kriminalisasi dalam ketentuan pidana Pasal 55 dan 56 UU Nomor 5 Tahun 2011 tentang Akuntan Publik dapat diketahui dari proses perdebatan yang dilakukan Panja komisi XI maupun Risalah persidangan perkara No 84/PUU-IX/2011, yaitu: (1) Konstruksi dalam formulasi norma didasarkan pada argumentasi perlunya perlindungan hukum kepada masyarakat, khususnya masyarakat pengguna jasa Akuntan publik; (2) Konstruksi yang kedua didasarkan pada aspek kepastian hukum. Aspek kepastian hukum ini dikaitkan dengan formulasi yang lebih jelas dan spesifik terhadap perbuatanperbuatan yang dilarang dan diberikan sanksi pidana sehingga dianggap lebih spesialis (lex spesialis) dibanding dengan formulasi dalam KUHP yang pengaturannya lebih umum; (3) Konstruksi ketiga disandarkan pada terwujudnya aspek transparansi pelaporan keuangan oleh akuntan publik; (4) Konstruksi keempat disandarkan pada profesionalitas akuntan publik akan lebih meningkat dengan mengalihkan beberapa aturan kode etik seperti "kertas kerja" menjadi ranah publik sehingga dapat dibebani sanksi pidana; (5) Konstruksi

44 Keterangan Ahli Pemohon Himawan Estu Bagijo dalam sidang Perkara Nomor 84/PUU-IX/2011 tanggal 22 Februari 2012.

45 Ibid 
kelima disandarkan pada efek jera. Pemberian sanksi pidana ini diharapkan oleh pembentuk undang-undang dapat memberikan efek jera kepada akuntan publik yang nakal dan tidak melaksanakan tugasnya secara baik dan benar.

Konstruksi teori subsosialitas dalam kriminalisasi diwujudkan dengan memberikan model kriminalisasi yang diharapkan dapat memberikan keseimbangan dalam formulasi kebijakan penal, yaitu dengan menggunakan model pendekatan

\section{Buku}

Bambang Purnomo, 1978, Asas-asas Hukum

Pidana, Ghalia Indonesia, Yogyakarta.

Barda Nawawi Arief, 1996, Bunga Rampai

Kebijakan Hukum Pidana, Citra Aditya Bakti, Bandung. , 2005, Pembaharuan

Hukum Pidana: dalam perspektif Perbandingan, Citra Aditya Bakti, Bandung.

Brunk, C., 2001, "Restorative Justice and

Philosophical Theories of Criminal Punishment" in "Restorative Justice and Restorative Theologies Dialogue". Disertasi pada The Faculty of graduate Theological Union, Barkeley.

Chairul Huda, 2006, Dari Tiada Pidana tanpa Kesalahan menuju kepada Tiada Pertanggungjawaban Pidana Tanpa Kesalahan, Prenada Media, keseimbangan dan pendekatan asas hukum (pidana). Model pedekatan Keseimbangan merupakan rekonstruksi keadaan subsosial pada masyarakat. Artinya dalam kriminalisasi harus memperhitungkan berbagai aspek, in casu perlindungan masyarakat (sosiologis) dan perlindungan profesi. Sedangkan pendekatan asas hukum (pidana) dilakukan dengan mengkaji secara mendalam mengenai asas kesalahan/schuld, sifat melawan hukum/ ketercelaan Perbuatan dan harm principle.

\section{DAFTAR PUSTAKA}

Jakarta.

HLA. Hart, 1961, The Concept of Law, Clarendon Press, Oxford. , 1968, Punishment and Responsibility: Essays in the Philosopy of Law, Oxford University Press, London.

Michael Efferson, 1999, Criminal Law, Pitmann, London.

Nina Persak, 2007, Criminalising Harmful Conduct: The Harm Principle its Limit and Continental Counterpart, Springer, Netherland.

Smith and Hogan, 1996, Undang-undang Jenayah Bagian I Prinsip Umum, Terjemahan oleh Jamilah Abdul Rauf dan Raja Rohana Raja Mamat, Dewan Bahasa dan Pustaka, Kuala Lumpur.

Tamanaha, B.Z., 2001, A General 
Jurisprudenci of Law and Society,

Oxford University Press, London.

Wilson, William, 1998, Criminal law:

Doctrine and Theory, Longman Limited, UK.

Yasraf Amir Piliang, 2004, Dunia yang Dilipat: Tamasya Melampaui Batas-Batas Kebudayaan, Jalasutra, Yogyakarta.

Yesmil Anwar dan Adang, 2008, Pembaruan

Hukum Pidana: Reformasi Hukum, Gramedia Widiasarana Indonesia, Jakarta.

\section{Jurnal}

Douglas Husak, 2008, Why Criminal Law:

A Question of Content?, Journal Criminal Law and Philosophy Volume 2:99-122.

Green, 2007, "Why It's a Crime to Tear the Tag off Mattress, in Caron BeatonWells," Capturing the Criminality of Hard Core Cartel: The Australian Proposal", Melbourne University Law Review, Volume 313 November 2007, Melbourne.

Kimberley Brownlee, 2008, Justifying

Punishment: A response to Douglas Husak, Criminal Law and Philosophy, Volume 2 Issue 2 June 2008.

Uri j. Schild, 1998, Criminal Sentencing and Intelligent Decision Support, Journal Artificial Intelligent and Law, Volume 6: 151-202, Kluwer Academic
Publishers, Netherland.

\section{Makalah}

Aan Eko Widiarto, Faizin Sulistio, M. Achsin dkk, 2011, Draft Permohonan Judicial Review Nomor Perkara 84/ PUU-IX/2011, Tidak dipublikasikan.

Agus Sudaryanto, 2011, Kriminalisasi Profesi dan Profesionalisme Akuntan Publik dalam Undang-undang No. 5 Tahun 2011 sebagai Wujud Pelanggaran Asas Equality Before The Law (Suatu Perenungan Sebagai Bahan Pertimbangan Kaji Ulang Kebijakan), Makalah dalam diskusi untuk permohonan Uji materi UU Akuntan Publik, Tidak dipublikasikan.

Arsip dan Dokumentasi, 2011, Risalah Rapat Panitia Kerja (Panja) Rancangan Undang-undang tentang Akuntan Publik tanggal 31 Januari 2011, Jakarta, Dewan Perwakilan Rakyat Republik Indonesia (DPR RI).

Soetandyo Wignjosubroto, Hukum: Konsep dan Metode, Makalah disampaikan The 2nd Course On Strengthening Socio Legal Studies, Jakarta, 20-27 Mei 2008.

\section{Peraturan Perundang-undangan}

Risalah Sidang Perkara Nomor 84/ PUU-IX/2011 pada tanggal 2 Februari 2012. 